\title{
A Rare Case of Aggressive Multiple Myeloma in a Young Adult
}

\author{
Authors \\ Kondala Rao.D ${ }^{1}$, R.R.Ramya ${ }^{2}$, S.S.K.R Bhimeswara Rao ${ }^{3}$, Seshukumari.D ${ }^{4 *}$, \\ Ashwini.B ${ }^{5}$, Hruday Mohan ${ }^{6}$, Dhanusha.K ${ }^{7}$, Satyakumari.D ${ }^{8}$, \\ Haritha', Jagadeesh.M ${ }^{10}$, Manoj ${ }^{11}$ \\ R.M.C, KAKINADA \\ *Corresponding Author \\ Seshukumari .D
}

\section{Abstract}

Multiple Myeloma represents malignant proliferation of plasma cells derived from single clone.

The median age of presentation is 65 years, is uncommon before the age of 40 years.

Keywords: Multiple myeloma ,malignant proliferation, plasma cells, single clone.

\section{Introduction}

Multiple myeloma is a plasma cell disorder characterized by clonal stem cell proliferation of plasma cells. The median age of diagnosis is $70 \mathrm{yr}$. It is uncommon before the age of $40 \mathrm{yr}(2.2 \%$ incidence).

\section{Case History}

A 30 year old farmer presented with increased urine output of one month duration, easy fatiguability of one month duration.

Patient is neither diabetic nor a hypertensive.

Physical Examination- Patient is conscious coherent oriented, vitals stable, GCS- E4 V5 M6, pallor is present.

\section{Investigations}

$\mathrm{Hb}-7 \mathrm{gm} / \mathrm{dl}$

BUN-102mg/dl

Sr.creatinine- $7.4 \mathrm{mg} / \mathrm{dl}$

USG abdomen-large sized kidneys
Peripheral smear-normocytic normochromic anaemia

Bone marrow biopsy-90\% plasma cells

Sr. electrophorosis-M band not detected

Urine electrophorosis-albumin, alpha 2 and betaglobulins detected, gamma globulins not detected

Serum immuno fixation-lambda band detected

Serum lambda free light chain $=8160 \mathrm{mg} / \mathrm{dl}$

Serum kappa free light chain $=18.30 \mathrm{mg} / \mathrm{dl}$

Serum beta 2 microglobulin>20,500ng/dl

Renal biopsy- intratubular casts showing evidence of light chain restriction in DIF studies

Skeletal survey- osteolytic leisons in skull, $\mathrm{X}$ ray pelvis, proximal end of humerus. 


\section{JMSCR Vol||08||Issue||04||Page 411-413||April}

Bony lesions in Multiple Myeloma
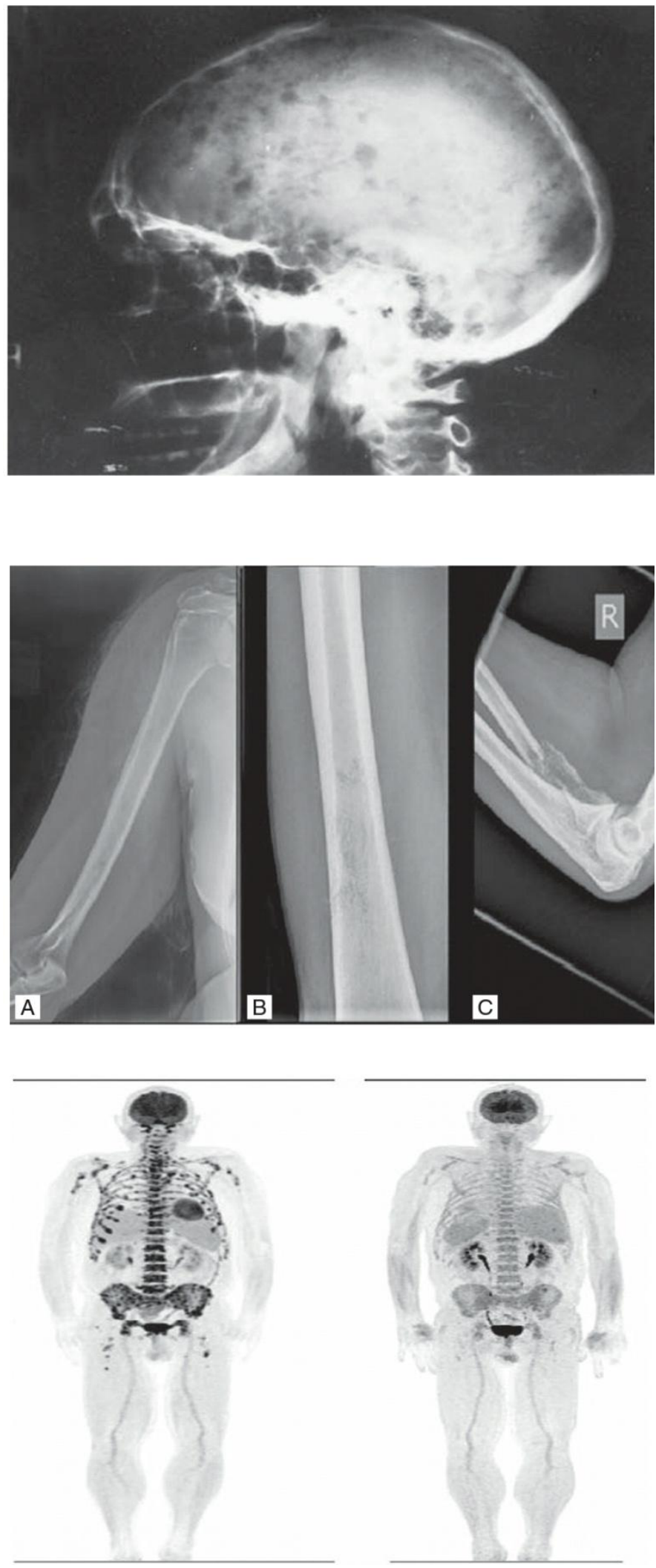

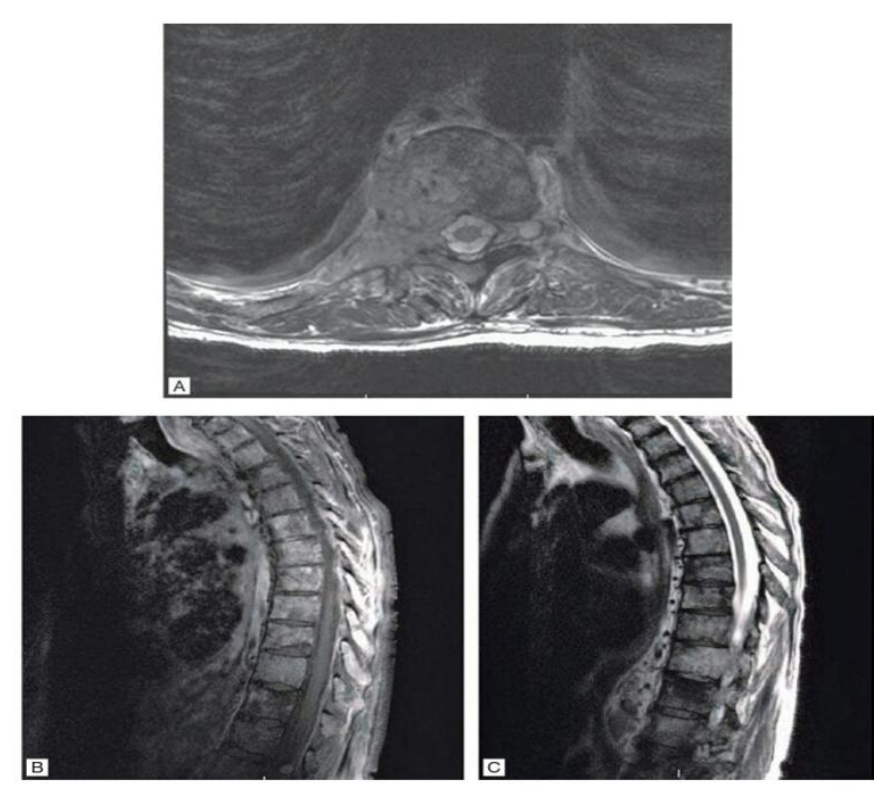

Binucleated and multinucleated malignant plasma cells in multiple myeloma

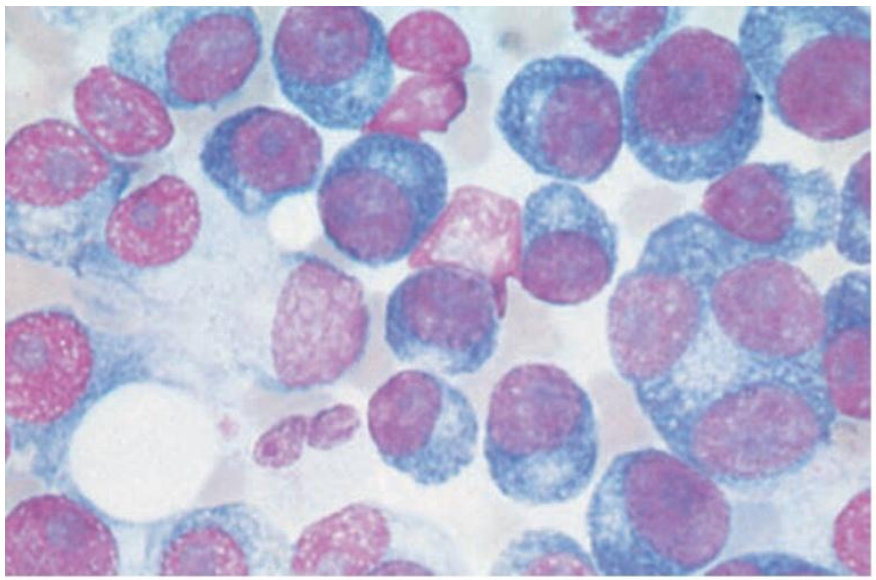

Degenerative patterns of serum electrophoresis and immunofixation.
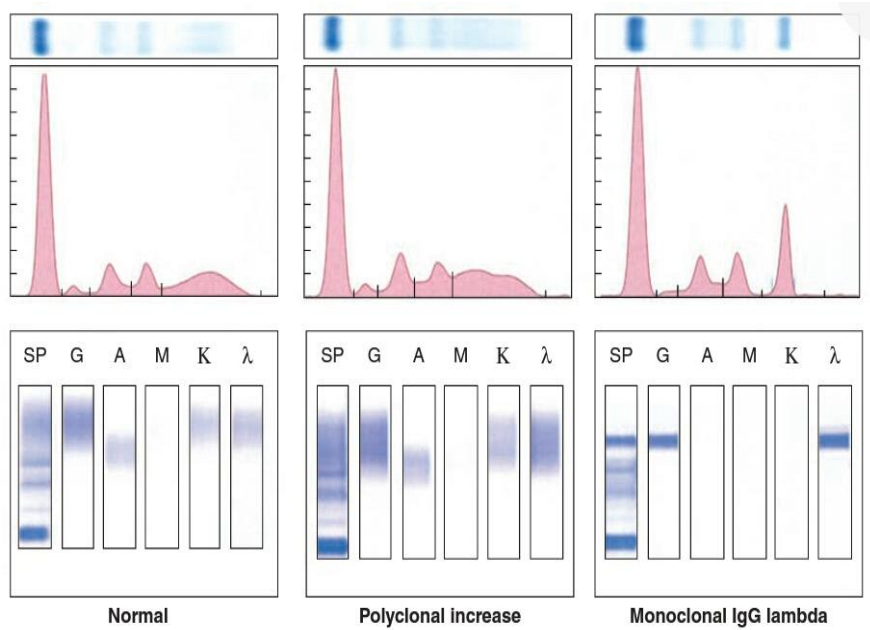


\section{Discussion}

Studies have shown that exposure to certain pesticides are known risk factors for multiple myeloma.

Our patient is farmer used to spray pesticides (Dimethicone 20\%, prophenophos and paraquat dichloride).

\section{Treatment}

Our patient was treated with VTD regimen (bortezomib, thalidomide, dexamethazone).

\section{Conclusion}

Despite the rarity of multiple myeloma in young adults, this diagnosis should be evoked when clinical, biological and radiological signs are in favour.

It has been suggested that young patients may present with more aggressive and less common disease features, frequently delaying initial diagnosis and thereby affecting outcomes.

\section{Reference}

1. Harrison's $20^{\text {th }}$ edition.

2. Devine H, et al. Semin oncol Nurs. 2017.

3. Stein bach M,' et al semin oncol nurs 2017. 